\title{
Experimentação Política da Amizade: Alteridade e Solidariedade nas Classes Populares ${ }^{1}$
}

\author{
Lívia Godinho Nery Gomes ${ }^{2}$ \\ Nelson da Silva Júnior \\ Universidade de São Paulo
}

\begin{abstract}
RESUMO - Pensar na possibilidade da amizade como espaço de experimentação capaz de irromper formas fixas de subjetividade e sociabilidade constituindo uma forma de resistência política representa um convite à alteridade numa relação experimental designada pelo compromisso irreversível com o outro. Este trabalho pretende descrever e discutir alguns resultados de uma pesquisa de mestrado que investigou as semânticas da amizade e a possibilidade da amizade se configurar como espaço de experimentação política. Buscando compreender como os laços de amizade podem constituir relações privilegiadas de experimentação de outras formas de relacionamento incompatíveis com os modelos individualistas e excludentes do capitalismo, entrevistou-se trabalhadores de cooperativas populares sobre as suas histórias de amizade. Os resultados dessa pesquisa destacam que os laços solidários que florescem entre amigos nas classes populares escapam aos imperativos neoliberais e resistem à situação de opressão, revelando modos criativos e astuciosos de enfrentamento de condições espoliantes, contribuindo para reverter situações de penúria.
\end{abstract}

Palavras-chave: amizade; alteridade; experimentação; solidariedade; resistência.

\section{Political Experimenting of Friendship: Otherness and Solidarity in the Lower Class Population}

\begin{abstract}
To think about the experience of friendship as a space of experimentation which may bring about fixed forms of subjectivity and sociability, thus constituting a form of political resistance, represents an invitation to a state of otherness in an experimental relationship designated by the irreversible commitment with the other. This paper intends to describe and discuss some results of a research elaborated in a Master's Dissertation project which investigated the semantics of friendship and the possibility of friendship turning into a space of political experimentation. Trying to understand how friendship ties may constitute privileged forms of experimentation of other forms of relationship, incompatible with the individualist and excluding models of capitalism, the authors conducted several interviews with workers of popular cooperatives (an autonomous and non-hierarchical form of work-group organization) about their friendship histories. The results of this survey highlight that the solidarity ties that flourish among friends of the lower class working groups do not coincide with the neoliberal imperatives but rather resist against oppressive situation, revealing creative ways of facing unfair working conditions, thus contributing to revert them.
\end{abstract}

Key words: friendship; otherness; experimentation; solidarity; resistance.

A experiência intersubjetiva encontra-se no centro da compreensão contemporânea dos processos de constituição de subjetividade, configurando uma ética de imprescindibilidade do outro para a produção do si mesmo, na qual o outro aparece como irredutível, na sua alteridade absoluta. Figueiredo e Coelho Jr. (2003) apontam que é no trabalho de Lévinas $(1993,2005)$ que o outro é pensado de fato como uma radical alteridade, a qual sempre me precede e me excede numa relação de intersubjetividade traumática: a subjetividade nasce nessa dimensão intersubjetiva do encontro

1 O presente artigo refere-se a uma parte da Dissertação de Mestrado da primeira autora sob orientação do segundo autor, intitulada Semânticas da amizade e suas implicações políticas. Familialismo e alteridade entre amigos nas classes populares. Esta pesquisa foi realizada com apoio da bolsa do CNPq.

2 Endereço: Alameda Ministro Rocha Azevedo, 373, apt. 71 B, São Paulo, SP, Brasil 01410-001. E-mail: liviagng@ig.com.br do outro que sempre requer esforço e trabalho, produzindo dor e sofrimento num processo de abertura e acolhimento do outro em sua alteridade; essa experiência traumática do outro implica processos de transformações, deslocamento e reconstituição das partes implicadas.

A relação intersubjetiva para Lévinas (1993, 2005) é, portanto, sempre traumática, porque implica transformações e transformações implicam trabalho e dor; o contato com o outro sofre o inevitável impacto de adaptação incompleta, da impossibilidade de um perfeito ajustamento, sendo traumático porque causa fraturas e requer trabalho em processos de inadaptação entre singularidades.

O presente artigo pretende, portanto, descrever e discutir alguns resultados de uma pesquisa de Mestrado que investigou a qualidade política da amizade, iluminada por Arendt (1993), Derrida (1997), Ortega (1999, 2000), entre outros, como relação na qual sujeitos em suas alteridades encontramse desestruturando-se, num espaço "agonístico" que favorece questionamentos de pontos de vista fixos, permitindo des- 
locamentos e a experimentação do surpreendente, de onde ações políticas inéditas podem se perfazer.

\section{O chamado do rosto: encontros traumáticos e alteridade}

Lévinas (1993) pensa o encontro com o outro como uma relação traumática na qual a presença desse outro impele, comanda, a partir do seu rosto, uma resposta - entendida como responsabilidade pelo outro. $\mathrm{O}$ caráter ético do conceito levinasiano de rosto funda-se na compreensão de que seres humanos são vulneráveis uns aos outros, ao apelo do rosto do outro. A experiência de estar exposto a outrem implica já generosidade; o ser visitado por outro me traumatiza e me afeta, sendo impossível rescindir a responsabilidade por esse outro. A leitura levinasiana da relação intersubjetiva pressupõe que o encontro com o outro implica reverência; "(...) o rosto impõe-se a mim sem que eu possa permanecer surdo a seu apelo, ou esquecê-lo, quero dizer, sem que eu possa cessar de ser responsável por sua miséria. A consciência perde sua prioridade." (Lévinas, 1993, p. 60).

Nesse sentido, para Lévinas (1993), a relação com o outro é traumática, pois é essencialmente um espaço intersubjetivo no qual alteridades são questionadas e se desestabilizam num movimento de não-incorporação, no qual o outro nunca é englobável, assimilável.

Portanto, de acordo com Lévinas (1993), a dimensão ética da visitação é anunciada pela presença do rosto como uma ordem irrecusável - "a nudez do rosto é indigência e já súplica na retidão que me visa" (Lévinas, 1993, p. 60), um mandamento que possibilita o questionamento da consciência num movimento no qual, diante da exigência do outro, "o Eu" tem a sua soberana coincidência consigo diluída, expulsando-se do repouso - identificação em que a consciência retorna triunfante a si mesma para repousar sobre si. $\mathrm{O}$ "eu", ao perceber o rosto como outro alguém, questiona-se e se desestabiliza, esvaziando seu imperialismo e egoísmo, confirmando sua unicidade na medida em que ninguém pode responder a esse rosto (ao outro) em seu lugar.

Portanto, de acordo com Lévinas (1993, 2005), é na dimensão inter-humana, no encontro com o outro em sua radical alteridade numa relação assimétrica, sem preocupação com reciprocidade, que o eu é interpelado, despertado da sua "embriaguez de si mesmo", sendo arrancado de sua primordialidade tornando-se responsável, antes de tudo, por esse outro que me convoca.

Esse despertar por outrem, o ser capturado, tornando-se refém desse outro que me comanda uma resposta, consiste no encontro ético levinasiano, no qual o eu é interpelado pelo outro numa condição de não indiferença por esse outro que me ordena, sem escravidão ou subjugação, pois é nessa convocação pelo outro que me diz respeito que o eu se descobre e se desperta.

Segundo Lévinas (1993, 2005), o encontro com outrem é já minha responsabilidade por ele; o seu chamamento, sua súplica que me exige uma resposta, questiona-me, faz apelo à minha responsabilidade por sua morte, como um apelo irresistível a não deixá-lo sozinho ou morrer só - aquilo que é próprio do "amor sem concupiscência".
A dimensão intersubjetiva, como acontecimento ético, que Lévinas $(1993,2005)$ destaca requer dor e esforço no encontro com o outro que é sempre indiscernível e que me interpela, exigindo solicitude em sair-de-si-para-o-outro, condição em que o eu é convocado para a seriedade do existir-para-outrem na qual a aventura existencial do próximo importa antes que a sua própria - o que me intima responsabilidade por esse outro e até mesmo o sacrifício de morrer por ele.

Esse amor comandado pelo rosto de outro solicita uma resposta, uma atenção cuidadosa, um apelo irresistível de não deixá-lo só, em outras palavras, no encontro com o outro, o eu torna-se questionado e investido pela alteridade irredutível do outro, responsável por este numa condição de não indiferença diante de sua morte e sofrimento.

Então, na leitura de Lévinas (1993, 2005), a subjetividade humana surge, constitui-se no encontro ético de acolhimento do outro como rosto, na sua absoluta estranheza, nesse sentido, a alteridade é constitutiva da subjetividade. A sociabilidade na relação faca-a-face constitui uma chamada, um apelo irresistível, pois me obriga e exige de mim uma resposta; a percepção do "absolutamente outro" nessa relação é inesgotável, insaciável, pois configura um encontro que me põe em fome crescente; a percepção de alguém alimenta aumentando a fome, o outro que me visita é como uma espécie de pão que se dá a comer sem desaparecer, sem diminuir. "O desejável não preenche meu Desejo, mas aprofunda-o, alimentando-me, de alguma forma, de novas fomes". (Lévinas, 1993, p. 56).

Essa imprescindibilidade do outro para a produção do si que é central no pensamento de Lévinas (1993, 2005), concebendo a relação intersubjetiva como espaço essencialmente de afetividade, de acolhimento do outro em sua alteridade no qual há afetações e transformações de subjetividade, encontra-se presente na discussão derridiana e foucaultiana de amizade como espaço de experimentação aberto ao outro - que não é idêntico a mim, possibilitando uma relação agonística de produção de subjetividades e de irrupção do imprevisto.

Nesse sentido, a subjetividade e a sociabilidade possuem um caráter ético no encontro com o outro. A relação intersubjetiva tem um caráter "agonístico", o outro é indispensável para a produção do si mesmo pois, no encontro com um outro, na situação face-a-face, os sujeitos envolvidos incitam-se mutuamente possibilitando uma desestruturação que geram possíveis questionamentos e transformações de suas subjetividades.

Segundo Ortega (1999), a amizade entendida na concepção foucaultiana como uma "estética da existência", como espaço de intersubjetividade "agonística", ressaltando a heterogeneidade no encontro com o outro que não deve ser suprimida na busca de uniformidade, representa a possibilidade de experimentar e reinventar formas de existência, recusando modos de subjetividade e sociabilidade dominantes.

É na trama das relações cotidianas que a amizade pode compor relações de experimentação "agonística" nas quais os sujeitos podem desestruturar-se, tendo suas subjetividades modificadas, cuja força concerne à dimensão da produção de subjetividade, pois aponta para a emergência de novos sujeitos sociais que juntos podem perfazer ações políticas ino- 
vadoras. Sader (1988) destaca essa dimensão de resistência política que pode ser travada coletivamente no âmbito das relações diárias ao ressaltar a irrupção de novos sujeitos, novos, pois organizaram-se coletivamente em suas lutas cotidianas favorecendo a formação de movimentos sociais populares da região de São Paulo entre 1970 e 1980, os quais ampliaram as redes de sociabilidade e ação, configurando novos padrões de ação coletiva, abrindo novos espaços políticos - o cotidiano das classes operárias.

Os movimentos sociais dos trabalhadores que compõem o "novo sindicalismo" nos anos 1970, como nos mostra Sader (1988), revelaram uma nova configuração das classes operárias, as quais passaram a se apoiar em outras estratégias discursivas, pautadas na contestação, politizando espaços antes silenciados, constituindo novas formas de expressão a partir da ação direta dos trabalhadores que repensaram o cotidiano das classes populares denunciando a condição de opressão.

Esse outro discurso da condição operária, elucidado por Sader (1988), reivindica direitos, fala das injustiças a que são submetidos e que podem ser vencidas quando os trabalhadores se unem e lutam. Os movimentos sociais revigoram a cidadania no cotidiano das classes trabalhadoras por meio das lutas em que os operários organizam-se criativamente de diversas formas, em experiências de resistência travadas no interior das fábricas, dos sindicatos, reveladas pelas greves e relações solidárias entre os operários que buscavam transformações e melhorias das condições de trabalho. Mobilizações coletivas que se estenderam aos moradores de periferia nas reivindicações de transportes, creches, escolas, que passaram a se organizar em associações de bairros, clube de mães.

Em seu belíssimo livro, Sader (1988) ressalta como a dinâmica dessas "pequenas lutas" cotidianas, antes consideradas "lutas por migalhas", liberam energia e criatividade no cotidiano das classes operárias em movimentos politicamente organizados cuja potência aponta para a emergência de novos sujeitos sociais que se experimentam e se descobrem aptos a conquistarem e realizarem ações significativas que resistem às condições opressivas, produzindo transformações relevantes em suas vidas.

Ao falar da grandeza desse "trabalho miúdo" que estava sendo realizado nos bairros, fábricas e sindicatos, Sader (1988) destaca inúmeras experiências travadas nas lutas diárias dos trabalhadores por grandes causas, nas quais a mobilização coletiva dos operários irrompeu transformações e ganhos significativos; o autor destaca uma determinada fábrica onde houve a mobilização para exigir que o café fosse servido de modo a permitir a livre movimentação dos operários os quais foram atendidos; em uma outra, os operários se negaram a fazer horas extras enquanto não obtivessem aumento do salário e foram vitoriosos; na Arno, contra o preço e a má qualidade das refeições, os operários fizeram um boicote ao restaurante da empresa até obter o congelamento dos preços e melhoria na refeição, sobre esse evento o autor aponta que: “(...) Ao se sentirem que haviam conseguido agir coletivamente, enfrentando a chefia, ficaram eufóricos. Os efeitos se fizeram sentir: os preços que iriam aumentar ficaram um ano e meio congelados e a qualidade os surpreendeu" (Sader, 1988, p. 247):
(...) strogonof, bicho! Eu não conhecia. Maça de sobremesa, Chambourcy de sobremesa, uma maravilha! Duas misturas, duas saladas (uma cozida, uma crua). Ficou uns seis meses mais ou menos assim. Depois começou a piorar, aí é outra história. Agora, o fruto disso aqui, nós formalizamos um grupinho que depois levou várias lutas lá... (...) (Depoimento cedido a Sader, 1988, p. 247, grifos meus).

É nesse sentido que as relações de amizade podem compor uma comunidade coletivamente organizada - da qual emergem novos sujeitos -, impelidos pela realização de ações inovadoras, que Derrida (1997) e Foucault (1981) falam da amizade como espaço de experimentação política. É nesse sentido, indicado por Sader (1988), de que as lutas do dia-a-dia compõem um aprendizado de cidadania nas quais as privações são pensadas enquanto injustiças podem ser revertidas se houver união e luta por seus direitos, que os laços de amizade configuram-se como uma relação favorável à mobilização dos sujeitos para modificar e transformar o cotidiano, compondo relações experimentais de resistência e enfrentamento da condição de aviltamento e dominação, das quais podem irromper ações políticas inéditas - como apontam Arendt (1993), Derrida (1997) e outros.

\section{Experiência discursiva da amizade e a experimentação política}

Para Arendt (1993), a mais importante das virtudes políticas é a amizade. A relação de amizade se configura como espaço privilegiado do agir e do falar - experiências eminentemente políticas e inter-humanas. Agir, no sentido arendtiano do termo, é, antes de tudo iniciar, começar o que não é previsto, o que ainda não existe entre nós, no mundo.

Com a sua teoria performativa da ação, Arendt (2001) aponta uma ação política como acontecimento e começo, como interrupção de processos automáticos. As ações humanas se caracterizam pela ausência de limites e pela imprevisibilidade das conseqüências. O agir constitui uma história cujo desenlace é desconhecido. Em outras palavras, na esfera da ação política é precisamente o inesperado que acontece.

Portanto, agir entendido como experiência política implica a parceria, a companhia dos outros. A ação, nesse sentido arendtiano, possui caráter não-violento e não-coercitivo na medida em que ela necessita dessa parceria, alcançada pela persuasão, por meio de conversas e não pela violência, para desempenhar um ciclo completo de experiência inaugural, de experiência inovadora. É nesse sentido, de espaço de experimentação e diálogo, que a amizade é, por excelência, uma atividade política que potencializa o agir. Em outras palavras, a amizade instaura o agir, possibilitando iniciar, perfazer com os outros a iniciativa, conquistando a adesão destes mediante a palavra e não mediante a coerção ou mando.

Portanto, a amizade na concepção arendtiana do termo é respeito e interesse pela opinião dos outros, não depende de intimidade, consiste no gosto pela opinião do outro, configurando uma relação desconcertante, "agonística", na qual é possível viver o deslocamento/questionamento do familiar, deslocando-se para o lugar dos outros. A amizade concebida na acepção política arendtiana possibilita experimentar a 
desestabilizadora condição de "vista embaçada" sentida ao enxergar o mundo através de "lentes outras". Além dessa experiência de descolamento do familiar vivida por uma alteração de ponto de vista, a relação de amizade entendida como experiência inter-humana do agir e do falar possibilita a experiência de ser visitado por outros, num contexto desafiador de coragem e ousadia da aparição pois, segundo Arendt (2001), é somente pela ação e discurso que o agente aparece e pode revelar-se.

O elemento político, na amizade, reside no fato de que, no verdadeiro diálogo, cada um dos amigos pode compreender a verdade inerente à opinião do outro. Mais do que o seu amigo como pessoa, um amigo compreende como e em que articulação específica o mundo comum aparece para o outro que, como pessoa, será sempre desigual ou diferente. Esse tipo de compreensão - em que se vê o mundo (como se diz hoje um tanto trivialmente) do ponto de vista do outro - é o tipo de insight político por excelência. (Arendt, 1993, p. 99).

Além da experiência discursiva, a amizade como uma relação política aberta à experimentação - da qual nos fala Arendt (1993), Derrida (1997), Ortega (1999, 2000) - implica a dimensão afetiva do acolhimento e respeito ao outro em sua alteridade, como um espaço intersubjetivo no qual os sujeitos estão em mesma condição de revelação/aparição e de escuta acolhida e respeitosa - condição de igualdade política - podendo mostrar quem são e conhecer os outros.

\section{Método}

Esta pesquisa foi desenvolvida com trabalhadores de cooperativas populares na Universidade de São Paulo. Os dados provêm da participação no cotidiano de três cooperativas durante o período de um ano, registrada em diário de campo, e da análise das sessões de entrevistas com os cooperados $^{3}$. Todos os sujeitos entrevistados são adultos com faixa etária maior que 20 anos e moram em bairros periféricos de São Paulo.

Este trabalho utilizou a descrição etnográfica como metodologia interpretativa das narrativas de amizades.

\section{Resultados e Discussão}

A compreensão da relação de amizade como abertura ao outro em sua alteridade implica um espaço intersubjetivo traumático que exige dor e esforço num contexto de inadaptação próprio do contato com a alteridade, supondo a qualidade daquilo que Silva Júnior (1999) aponta como a passividade da incerteza e a adoção do abismo como fonte do olhar. Arendt (1993), Derrida (1997) Ortega (1999, 2000) e outros destacam a relação de amizade em sua condição de perhaps (talvez) como vínculo intersubjetivo que pressupõe a reverência e acolhimento levinasianos, no contato com a alteridade, na qual as experiências eminentemente políticas

3 Todas as entrevistas foram gravadas, com prévia autorização dos sujeitos, os quais também assinaram termo de consentimento livre informado que garante a não-identificação pessoal dos sujeitos e da instituição. do agir e falar possibilitam a irrupção do imprevisto - tal como apontado por Arendt (1993, 2001).

Os discursos contemporâneos de amizade ligam-se à complexa tessitura das relações contemporâneas imbricados com toda a complexidade e ambigüidade que as caracterizam. É sobre esses discursos que, a partir de agora, desdobraremos nossa atenção, mais precisamente, na inesgotável busca de apreendê-los.

\section{Encantamento da hospitalidade amiga}

É sobre a amizade, na acepção arendtiana de escuta e acolhida respeitosa do outro em sua alteridade, na qual se vive o que é próprio da solidariedade, da hospitalidade que Pedro nos fala ao narrar uma história de amizade que ele considera muito marcante. Ao pedir para contar uma história de amizade foi esta que ele primeiro destacou:

Nossa tem várias. Eu vou contar assim, tipo eu sou daqui, mas também vou muito pro Rio, eu tenho família no Rio, e tipo uma amizade que eu tive lá, que logo chegando no Rio com medo por ser uma cidade violenta e tal, aí que eu conheci uma pessoa muito legal, conheci na praia, só que a gente morava no mesmo local, no mesmo morro, eu estava de visita lá, então eu encontrei essa pessoa no morro, o nome dela é (Jasmim), aí tipo assim, foi a pessoa que tipo foi me explicando oh você não pode ficar tal hora na rua, que acontece isso e isso, e eu fui explicando as coisas daqui, que era diferente, não era tão violento e tal, e tipo eu fui a primeira vez pro Rio eu tinha uns treze anos eu conheci ela, tipo agora eu vou final de ano passar as festas lá, é uma amizade assim que estamos até hoje mas, foi uma coisa natural, sabe, tipo nos encontramos na praia e tipo voltamos a se encontrar no mesmo lugar de moradia, (...) porque eu tinha medo, tinha que ter um conhecido lá, que eu só tenho uma prima lá, então eu ia pra casa da minha tia lá e ficava, então não tinha quem muito conversar e através dessa amizade de uma pessoa só da (Jasmim), aí eu fui conhecendo primos dela, irmãos tal, aí hoje no local que eu vou lá eu conheço bastante gente através de uma pessoa que tipo pra mim foi solidária, chegou, conversou e se interessou, porque eu era um rapaz de fora, e tipo fez com que eu conhecesse o bairro, então foi uma amizade assim, é dificil hoje em dia você, eu acho, que é meio difícil você chegar num lugar e não saber conversar com ninguém, não se interagir com a pessoa assim, aí você tem que procurar uma pessoa que se interessa da sua história assim e querer conhecer o lugar e essa amizade pra mim foi importante por causa disso, hoje em dia eu agradeço a ela quando eu vou lá, quando eu estou lá na cidade, muitas pessoas me conhecem através dela (...) agora eu vou deixar mais claro, porque assim, no dia que a gente está hoje, se você chega num local, e tipo tem um rapaz ou uma moça assim, pra se aproximar um do outro e ter a iniciativa de conversar, é muito difícil hoje em dia, então ela foi uma pessoa assim que eu conheci, eu estava nadando, pegando onda e bati a cabeça na dela, aí ela falou você é de São Paulo, sou e tal, aí começou, mas eu estou aqui não conheço ninguém vim pra praia com minha prima, não conheço ninguém, aí do nada encontrei ela lá, você é da praia e tal não sei que, olha aqui é assim, não pode ficar até tal horário que é perigoso, conheço fulano, quer conhecer tal pessoa. (...) (grifos meus) (Pedro). 
De uma inusitada colisão entre as cabeças na praia, Pedro viveu a inquietante emoção do mal-estar sentido quando entramos num lugar desconhecido. Esse desamparo ou susto vivido por Pedro, que Derrida e Dufourmantelle (2003) nos falam como a comoção sentida quando se está em lugar não conhecido, aos poucos vai se esvaindo pelo gesto de hospitalidade de Jasmim. Pedro fala sobre o medo sentido por estar num lugar desconhecido e considerado violento, medo esse que passa diante do acolhimento no encontro com Jasmim. Esse gesto de hospitalidade de Jasmim - que Derrida e Dufourmantelle (2003) destacam ao ressaltarem a questão do político como sendo dada, significada a partir do outro, o estrangeiro - interrompe o mal-estar sentido por Pedro, fazendo-o sentir aquela emoção de quem recebeu flores inesperadas.

A postura cuidadosa de Jasmim com Pedro, seu acolhimento e escuta atenciosa, informam amizade que não depende de intimidade, relação na qual o gosto pela opinião do outro, a escuta e acolhida desse outro que me desestabiliza, possibilita a irrupção do imprevisto - tal como apontam Arendt (1993), Derrida (1997, 2003), Ortega (1999, 2000) e outros. Não é à toa que Pedro destaca essa amizade como especial, ele fala dessa escuta e acolhimento respeitosos, afirmando que Jasmim foi uma pessoa solidária, ele era um rapaz de fora e ela chegou, conversou, interessou-se por sua história, apresentou-lhe o bairro, suas peculiaridades, as pessoas do local. Ou seja, a amiga Jasmim, ao mostrar a sua comunidade para Pedro, elucida a qualidade da amizade de igualdade política, aquela condição de igualação política da amizade que Arendt (1993) diz alcançar, justamente, a comunidade. Essa amizade de abertura para o outro em sua alteridade, na qual se é visitado e devolvido pelo outro, permitindo o questionamento e deslocamento do familiar, possibilita a irrupção do imprevisto, aquilo que ainda é sem lugar entre nós. Desse encontro de Pedro com Jasmim é o surpreendente, o imprevisto, que irrompe. É como se essa amizade abrisse porta pra infinitas possibilidades. No mínimo, a relação de Pedro com o Rio de Janeiro não será mais a mesma, ele mesmo conta que, quando chega lá, já sabe se localizar, sabe os horários que deve chegar e sair, já conhece outras pessoas; sem falar do que pode surgir dessas novas relações estabelecidas com outras pessoas, relações estas que foram desdobramentos de sua amizade com Jasmim.

Dufourmantelle (2003) afirma que "o futuro está dado como sendo o que nos vem do outro, disso que é absolutamente surpreendente" (p. 72); essa autora faz um questionamento por meio de uma analogia comentando que, em hebraico, "fabricar tempo" é equivalente a "convidar", ela enfatiza, portanto, a "estranha inteligência da língua que pressupõe que, para se produzir tempo, é preciso ser dois, ou antes, que é preciso que exista o outro" (p. 72). Arendt (1993) também ressalta que a qualidade daquilo que surge, daquilo que se produz depende da companhia de um outro. As ações políticas precisam da adesão e companhia dos outros, da luz pública advinda do testemunho do outro para atingir o ciclo de experiência inaugural, inovadora. É nesse sentido que o inesperado, o surpreendente, como qualidades da concepção política arendtiana, conferem à amizade um espaço privilegiado do agir e do falar, iminente de irrupção de experiências inéditas.
A amizade entendida como espaço intersubjetivo agonístico traumático, no qual o outro em sua alteridade afeta e desestabiliza, implica transformações e, portanto, dor - como apontado por Lévinas $(1993,2005)$ numa relação em que os sujeitos são mutuamente implicados e capturados. Derrida (1993) destaca que esse movimento de mútua afetação no qual o estrangeiro questiona a realidade local do hóspede e este também questiona esse, essas substituições em que o "hospedeiro torna-se hóspede do hóspede" e "o hóspede torna-se hospedeiro do hospedeiro" são as leis incondicionais da hospitalidade, fazendo cada um, refém do outro. Nesse sentido, não é só Pedro que sai diferente, mas Jasmim também sai modificada, como naquela estranha lógica, mas tão esclarecedora, que Derrida (1993) aponta do "senhor impaciente que espera seu hóspede como um libertador, seu emancipador" (p. 107). O gesto de hospitalidade de Jasmim, de escuta e acolhida atenciosa, ilumina aquilo que Derrida (1993) chama de hospitalidade incondicional:

Em outros termos, a hospitalidade absoluta exige que eu abra minha casa e não apenas ofereça ao estrangeiro (provido de um nome de família, de um estatuto social de estrangeiro, etc.), mas ao outro absoluto, desconhecido, anônimo, que eu lhe ceda lugar, que eu o deixe vir, que o deixe chegar, e ter um lugar no lugar que ofereço a ele, sem exigir dele nem reciprocidade ( $a$ entrada num pacto), nem mesmo seu nome. A lei da hospitalidade absoluta manda romper com a hospitalidade de direito, com a lei ou a justiça como direito. (Derrida, 1993, p. 25).

\section{A humanidade da conversa entre amigos e a possibilidade de alargar-se; ou o "fala que eu te escuto" de Pedro}

De acordo com Arendt $(1993,2001)$, o mundo torna-se humanizado quando é transformado em discurso e somente com o outro que se pode pôr em palavras como o mundo aparece. Essa condição de "abertura aos outros" que possibilita ver o mundo a partir de um deslocamento de posição, em que ver o mundo no lugar do outro é a qualidade essencialmente política da amizade. $\mathrm{O}$ aspecto político do diálogo entre amigos do qual Arendt (1993) fala supõe uma relação de amizade entendida como espaço intersubjetivo traumático - do qual nos fala Lévinas (1993), em que o contato tenso com o outro em sua alteridade, exige transformações que implicam dor e esforço num movimento de mudança de posicionamento, possibilitando um espaço de compartilhamento no qual se vê o mundo a partir do lugar do outro, o que permite o deslocamento de posição para alcançar um pensamento mais abrangente, mais complexo, conforme apontado por Margarida:

(...) que nem eu falava, nesse compartilhar você acaba compartilhando idéias e pensamentos da forma que você se coloca diante do mundo e diante das pessoas e às vezes você tem respostas pra n coisas, mas exatamente por causa dessas diferenças, assim, você pensa de tal jeito diante desse assunto, entendeu, eu Margarida penso de outro, de repente a minha maneira que estou vendo, que eu estou enxergando as coisas é diferente da sua, e da maneira que eu estou vendo está me causando problema e eu não estou sabendo olhar, o seu olhar 
de repente é a solução para o meu problema, e aí nesse compartilhar, conversando, dialogando, falando eu aprendo $e$ há transformação, entendeu, transformou a minha linha de pensamento, transformou a maneira que eu vejo e que eu olho as coisas aí com o que você me traz com o que você me fala eu começo olhar a mesma coisa mas com outro olhar, com outra visão mais aberta, entendeu, e acaba aprendendo, aí é onde surge a transformação. (grifos meus) (Margarida).

A relação de amizade configura esse espaço discursivo no qual é possível, a partir do outro, ver o mundo com outro olhar, com uma visão mais aberta, conforme nos falam Margarida e Arendt (1993). Essa qualidade discursiva da amizade, na qual a conversa entre amigos, a troca de opiniões que possibilita essa abertura de visão, revela a dependência do outro para alcançar o aprimoramento e ampliação do pensamento, como nos fala Pedro:

(...) o amigo ele já conhece a expressão do outro assim, quando está preocupado, quando estáfeliz, então, ofala que eu te escuto é isso assim, eu já resolvi muitos problemas assim, porque às vezes a cabecinha da gente não pensa, não pensa, precisa de duas e duas seria o que, um amigo que escuta você (...), esse é o fala que eu te escuto como também já fiz com outros amigos também, outros problemas também, briguinhas, rixas ali, com outras pessoas, falar oh, pela experiência que eu tenho não vale nem a pena, não faz isso e deixa, não sei que, eu acho que é isso assim, resolver problema juntos assim, (...) (grifos meus) (Pedro).

A experiência discursiva da amizade na qual existe uma relação de igualdade política e os amigos como agentes e falantes compartilham perspectivas de como se põe na vida, torna o mundo humanizado. "Esse humanitarismo a que se chega no discurso da amizade era chamado pelos gregos de filantropia, o 'amor do homem', já que se manifesta na presteza em compartilhar o mundo com outros homens". (Arendt citada por Bauman, 2004, p. 177).

A qualidade discursiva da amizade implica uma relação de abertura ao outro em que a troca de opiniões no diálogo possibilita a experimentação do deslocamento de perspectivas e uma relativização das idéias e pensamento diante dos incalculáveis posicionamentos sobre o que é próprio desse mundo. Segundo Bauman (2004), o grande mérito de Lessing, na opinião de Arendt, foi ficar satisfeito com essa infinidade de opiniões que surgem nas discussões humanas dos assuntos desse mundo:

(...) A grandeza de Lessing não consiste meramente no insight teórico de que não pode haver uma única verdade no mundo humano, mas em sua alegria pelo fato de que ela não existe e que, portanto, o infindável discurso entre os homens jamais terminará enquanto estes existirem. (Arendt citada por Bauman, 2004, p. 177).

\section{A desconcertante e acolhedora conversa entre amigos: convite a devanear-se em horizontes outros}

O vínculo discursivo da amizade em que os amigos agem e falam em condição de igualdade política implica uma relação de abertura ao outro, do gosto pela opinião dos outros. O partilhar de opiniões que a experiência do ouvir e falar possibilita na conversa entre amigos configura a relação de amizade como espaço, ao mesmo tempo, confortante e inquietante de trocas de idéias, informações, vivências, etc. permitindo, por meio desse ato de escuta acolhida e compartilhamento, que a vida se torne mais "leve", como nos conta Gabriel:

(...) e quando você encontra uma pessoa que te ouve e tem uma resposta amiga, até mesmo um conselho pra te dar, eu acho que isso se torna um tanto quanto, um tanto importante na vida de alguém, porque todos precisamos de alguém pra desabafar, se você não tem, a sua vida fica um pouco pesada, o clima fica muito pesado, e quando você encontra alguém que faz o que você faz com as outras pessoas é um alivio, porque as outras pessoas que você ouve não te dão ouvido, só quer falar, falar, falar e você ali parado ouvindo, mas quando você encontra assim realmente uma pessoa pra te ouvir também é muito bom, aí é uma troca, você ouve, e depois eu faço a mesma coisa, então, nós vamos trocando informações ali até chegar em determinado ponto que dependendo da situação, dependendo do que está acontecendo acaba se resolvendo de maneira mais simples e fácil, porque conversando fica tudo mais fácil pra você resolver alguma coisa. (grifos meus) (Gabriel).

Essa dimensão de alívio da conversa, afirmada por Gabriel, também aparece nos discursos dos demais sujeitos entrevistados que destacam a relação de amizade como espaço privilegiado de escuta atenciosa, de acolhimento e trocas de experiências, no qual é possível viver a beleza do compartilhamento de alegrias, tristezas e do prazer de uma boa conversa:

Então, o que eu estou te falando assim, contar com um amigo que você tem um problema, tem uma alegria, quando você tem alegria você quer compartilhar com todos, especificamente você chega no amigo e fala ah, eu estou muito alegre por causa disso que está acontecendo comigo e tal, beleza, aí quando tu tem um amigo mesmo aí você tem uma decepção na vida ou está com um problema aí você chega no amigo também e fala oh, preciso contar meu problema pra alguém, aí, ele é atencioso, ele te escuta, ele vai, coloca opiniões, oh, você pode encontrar esse caminho, que eu também já passei por essa experiência, também, então, não é por aí, você está se desesperando, você não pode agir assim, então, esses assim que eu falo que, é esses que fala que eu te escuto, (...) (grifos meus) (Pedro).

(...) a gente fica brava e fica uns dias sem se ver, aí sente necessidade de uma conversar com a outra pra falar das coisas que aconteceram, é pra contar o que aconteceu, pra contar o que está acontecendo, ou se está chateada no trabalho, ou se brigou com alguém ou se discutiu com alguém ou se está muito bem, de repente quer compartilhar felicidade, assim, é um monte de coisa, é muita coisa porque é muito tempo juntas assim, mas a gente sempre está se auto aprendendo (...) ( grifos meus) (Margarida)

(...) nós duas, a gente sentava, conversava, quando a gente terminava todo o serviço, a gente sentava na área e a gente ficava conversando bastante tempo, sentada ali, eu gostava muito disso quando eu estava com ela, de a gente conversar. 
Ela conversava, contava da terra dela eu contava de Londrina, porque a minha terra é Londrina, nasci no interior de São Paulo mas fui pra lá pequena, não lembro muito bem, mas eu lembro de Londrina, onde eu morei, e ela contava muito da terra dela e era muito gostoso ver a história que ela tinha pra contar, a gente tem a mesma idade, mas a história de vida dela é assim, sabe, foi bastante complicada também, e tinha que pescar, pegar caranguejo, até sabe, eu viajava nos causo dela, então, foi muito bom na época, e eu tenho saudade dela, (...) (grifos meus) (Miosótis)

A dimensão política da conversa entre amigos, destacada por Arendt (1993), é iluminada pela possibilidade de alçar vôos, de viajar em universos outros, como Miosótis afirma ("eu viajava nos causo dela"). O espaço discursivo da amizade permite a extraordinária experiência de se transportar nas histórias do outro, numa relação de escuta acolhida e compartilhamento de amores, desafetos, alegrias, tristezas - aquilo que é próprio da existência humana. Essa solicitude em ouvir, esse interesse pela história do outro, próprios das relações entre amigos como mostram os discursos acima, em que se vive a responsabilidade pelo drama do outro compartilhando tristezas e felicidades, compõem um sair-se de si para o outro como espaço aberto inerente de desprendimentos e deslocamentos que apontam para o alcance de um alargamento de idéias e opiniões, fazendo variar pontos de vista e registros de sensibilidade - o que qualifica o laço de amizade como um devaneio em que se avistam novos horizontes.

\section{Laços solidários que resistem e engrandecem: o amigo que permite experimentar o surpreendente e potencializa habilidades}

Pedro é fascinado por esportes, praticar alguma atividade esportiva é o que ele diz gostar mais de fazer nas horas livres. A beleza dessa relação de amizade em que o amigo dá a mão para Pedro aprender a nadar destaca a fascinante experiência de irrupção do surpreendente que o contato com a alteridade implica, como nos falam Arendt (2001), Derrida (1997), Ortega (1999, 2000) e outros, configurando uma relação que informa a abertura de infinitas possibilidades:

(...) tem amigo que ajuda que fala assim vou te ajudar, ensina e ajuda mesmo, tem vários, tipo, pra nadar, natação, no BNH também eu não sabia nadar, primeira vez que eu fui pular na água, eu quase me afoguei, aí chegou um rapaz assim, ele mora até perto de casa, também, só que atrás do colégio onde a gente estudou, aí ele falou, oh, você não sabe nadar, eu falei não sei nadar, eu quase morro e tal, tinha uns 11 anos, aí ele falou assim é o seguinte eu sei nadar, quer que eu te ensine, aí eu falei ah, eu quero; aí tal, foi pegando na minha mão, que na época não tinha bóia, mas só tipo, como é que eu posso falar, só, os meninos que tinham dinheiro mesmo, a gente pegava aqueles pedaço de isopor, assim, colocava em baixo da barriga pra, que é apoio para o nado, aí ele me ensinou a nadar, a gente criou amizade assim, começou me ensinando a nadar, depois jogava futebol junto, estudamos junto também, aí tipo tinha um dever assim, tinha matemática, sempre fui péssimo em matemática, e ele sempre foi bom, é uma diferença, aí ele fala assim, você é bom em português, também sou, aí eu te ajudo em matemática e tal, tem uma prova meio difícil, eu te passo até uma cola, você ver até cola ele passava, é errado, mas é amigo. Aí, me ajudava assim, então essas amizades a gente preza, conheço até hoje, ele também trabalha aqui na USP, às vezes, no trabalho a gente se suja, o cara trabalha bonitão, todo arrumado, então por onde ele me ver, oh (Pedro), pega na minha mão, e uma coisa que eu fico bem admirado assim, que eu falo esse cara é meu amigo mesmo, eu sinto firmeza, fico até emocionado, é quando esteja você onde estiver, tipo fazendo o que você faz, o cara é seu amigo desde lá de baixo, se ele te ver, ele está passeando de carro, está passando bem vestido, ele te cumprimentar, não tem preço isso daí, não tem preço, (...) Mas o que eu prezo é muito isso, então esse rapaz que eu estou falando agora, ele mora numa casa bem melhor que a minha, tem um conforto melhor, o irmão dele tem carro, o pai dele e a mãe dele tem um cargo bom, e ele tinha todo esse benefício, de ter bóia, ter pago um curso de natação, então ele me ensinou e na escola ele também me ensinou e hoje depois da gente adulto eu vejo ele aqui, onde me ver para, conversa, então é uma das amizades também que eu posso falar, sem palavras, (...) (grifos meus) (Pedro)

A solidariedade dessa relação informa a condição de abertura ao outro em sua alteridade, o vínculo de amizade que não pressupõe intimidade mas sim o gosto pelo outro, possibilitando que o imprevisto irrompa, configurando um vínculo de afetações e transformações mútuas. É o surpreendente que surge dessa amizade em que o amigo de Pedro, que já tinha tido a oportunidade de fazer curso de natação, ensina-o a nadar, potencializando seu gosto por esportes e possibilitando a Pedro fazer o que mais gosta - vínculo que extrapola a barreira econômica que impossibilitaria Pedro de aprender a nadar. É no sentido de que Pedro sai afetado, potencializado desse vínculo, que essa amizade configura-se como um espaço privilegiado de experimentação política que permite um movimento de deslocamento, de transformações, numa relação de mútuas afetações na qual o amigo de Pedro possibilita que ele cresça. A imprevisibilidade é a marca dessa relação de amizade de que nos falam Arendt (1993), Derrida (1997), Ortega (1999, 2000) e outros, em que a abertura ao outro é condição de deslocamentos e transformações, informando a necessidade da companhia do outro para que haja crescimento, para que as ações políticas, no sentido arendtiano, potencializem-se.

$\mathrm{O}$ atributo da amizade de romper com uma ordem estabelecida pode ser observado em duas outras histórias em que as relações de amizade possibilitam a irrupção do imprevisto, possibilitando a Pedro, que adora esportes, realizar seu sonho de trabalhar com esportes treinando um time de futebol. O sonho de Pedro é ser professor de educação física e mesmo não tendo condições financeiras atualmente para freqüentar uma academia, ele fala que aprendeu vários exercícios físicos com a ajuda de amigos, mostrando o encantamento de experimentar com o amigo a realização de um sonho, de divertir-se, de ter seu momento de lazer e aprender as atividades físicas, que é o que mais gosta de fazer, rompendo com a dificuldade do impedimento econômico - o que aponta a beleza da relação de amizade 
como espaço privilegiado de experimentação política, advertida por Arendt (1993), Derrida (1997), Ortega (1999, 2000) e outros:

(...) mas sempre fui fascinado por esporte assim, e sempre tive ajuda de amigos no futebol, em natação, aí a partir do momento eu pensei ah, eu quero me envolver no esporte pra sempre assim, fazer uma faculdade, prestar concurso pra esporte ou coisa parecida, (...) mas foi uma experiência boa e eu quero estar sempre envolvido, tem a turma que eu corro aqui dia de domingo, eu quando tiver oportunidade de fazer academia eu vou fazer, que tipo eu gosto de movimentar o corpo, está fazendo esporte, e sem contar que nesse lugar você também encontra muito amigos, têm vários exercícios, têm vários alongamentos, ginástica, que você vai sempre aprendendo, aí, é onde está envolvido os amigos também, olha vai ter uma corrida aqui, no vila lobos, vai ter um circuito $e$ tal, vem correr aí, sexta feira eu saí daqui, estava cansado, aí chegou um amigo meu lá em casa e falou assim, um amigo que eu não via faz tempo, trabalha pra caramba também, aí falou assim, (Pedro) vai ter um futebolzinho de seis e meia, você está fazendo alguma coisa, a gente vai jogar até umas nove horas, aí eu pensei nossa mas eu estou quebrado, aí eu tomei um banho, relaxei eu falei, ah, pode vim aí, aí foi lá, pra você ver como uma coisa puxa outra, eu conhecia só ele, os carinhas eram parceiro de serviço dele, lá, aí, me envolvi com o pessoal, joguei futebol, o pessoal gostou do meu jogo, $e$ falou oh pode vir toda sexta aíjogar que a firma paga a quadra aqui, pode vir aí cara, pra você ver, a gente já, através de um amigo já vai conhecendo outras pessoas e já vai fazendo o que mais gosta, que o que eu mais gosto é de fazer isso nas horas vagas, (...) (grifos meus) (Pedro).

O aspecto subversivo da amizade como espaço de experimentação, de circulação horizontal de trocas de idéias, conhecimentos, experiências entre amigos em que o surpreendente irrompe podendo possibilitar rupturas na ordem econômica dominante, também é informado na história de Girassol que aprende a dirigir com um amigo, extrapolando o impedimento econômico que a impossibilitaria realizar esse sonho:

(...) ele me ajudou muito, ele, coitado, ele comprou até um carro na época pra ajudar, na (cooperativa), ele colocou a disposição da (cooperativa) esse carro ele existe que aquele fiat uno que você já viu eu dirigindo, e pra fazer compra, né, e quando precisa de alguma coisa a gente liga pra ele, pô Toninho queimou isso, precisa disso, aí ele corre, sabe, faz, Toninho éo cara, ele é um grande amigo nosso, não só meu, como de toda cooperativa, todos aqui gostam dele. (Girassol)

(...) eu sempre sonhei em dirigir, eu tinha loucura pra aprender a dirigir, mas achava que nunca ia conseguir porque assim, eu vim de uma família muito pobre, muito carente mesmo, então eu achava que nunca ia conseguir, mas aí teve esse lance do Toninho, essa coisa de amizade que eu falei pra você, que é o Toninho aqui da FAU, ele falou assim, ah, meu, agora que tem a cooperativa meu, sabe alguém tem que aprender a dirigir lá (Girassol), e essa pessoa tem que ser você, entendeu, não você, mas tem as outras pessoas, mas quem se interessava mais era eu entendeu, aí ele falou, não, vou te ensinar, aí nas horas vagas e quando a FAU estava de férias, que os alunos daqui entram em férias em julho, e dezembro, nossa ele me ensinou a dirigir aqui no estacionamento, aqui, que era uma loucura, mas eu consegui, entendeu, ele que me ensinou, (risos) ele que me ensinou, um barato, (...) (grifos meus) (Girassol)

Esse laço de amizade que possibilitou Girassol aprender a dirigir, além de garantir-lhe autonomia, também a modifica enquanto sujeito, é Girassol enquanto singularidade que sai transformada desse vínculo. A amizade entendida por Arendt (1993), Derrida (1997) e Ortega (1999, 2000) como espaço de abertura ao outro, privilegiado de experimentação política, possibilita esse sentimento de transformação que se assemelha à emoção de sair modificado do encontro espectador/obra, em que o olhar a própria realidade sensível da obra como significado instaura-se numa hermenêutica aberta, uma relação de construção de sentidos. Esse sentimento de transformação, esse campo reflexivo que solicita uma abertura para o novo, para a alteridade - instaurado no processo de interpretação como uma percepção participativa e interessada na qual o olhar reconstrói a realidade viva da obra, construindo campos de sentidos - são suscitados na relação de amizade em que Gabriel aprende a tocar bateria com um amigo.

Pra mim foi ótimo, né, que era um a coisa que eu sempre quis fazer, desde quando eu tinha oito anos eu queria aprender tocar bateria e quando houve oportunidade, um ajudando o outro e nós fomos em frente, aprendi, e toquei durante cinco anos, se tiver que tocar hoje, eu toco também e assim foi, e através disso nossa amizade cresceu, e somos amigos até hoje,(...) (grifos meus) (Gabriel)

A relação de Gabriel com a música que essa amizade instaura, pode causar um processo de percepção e sensibilidade inteiramente novo. Nesse vínculo de amizade permeado pela música, no qual ambos são mutuamente afetados, não somente Gabriel e seu amigo modificam-se, mas as suas vidas podem mudar completamente tomando rumos inesperados. É no registro da subjetividade que Gabriel é transformado, torna-se outro pela relação musical com seu amigo. A possibilidade de tocar um instrumento musical realizado pelo laço de amizade pode mudar completamente o sentido da vida de Gabriel, permite uma nova relação com seu potencial criativo, além de potencializá-lo como sujeito desejante. Guattari e Rolnik (1986) afirmam que a ordem capitalística fabrica a relação do homem com o mundo e consigo mesmo. Segundo eles, as modificações da subjetividade não funcionam apenas no registro das ideologias, mas no próprio coração dos indivíduos em sua maneira de perceber o mundo, de se organizar no tecido urbano. Eles atentam que todo movimento de recusa e resistência aos modelos pré-codificados pela ordem capitalista econômica dominante diz respeito também à questão da produção da subjetividade, o que deverá ser levado em conta pelos movimentos de emancipação.

É no âmbito da subjetividade que Pedro, Girassol, Gabriel e os demais modificam-se a partir do espaço discursivo e de experimentação dos seus laços de amizades, o Pedro, que adora esporte, não é mais o mesmo depois que aprendeu a nadar com seu amigo; Girassol, que realiza seu sonho de 
aprender a dirigir com seu amigo, mesmo sem ter condições financeiras para isso, também transformou a relação consigo mesma e com a maneira de se articular na vida cotidiana; o contato de Gabriel com a música, ao aprender a tocar bateria com o amigo, pôde proporcionar uma outra percepção de realidade e sensibilidade completamente novos possibilitando uma redescoberta do seu potencial criativo. É nesse sentido de relação agonística na qual o contato com a alteridade permite deslocamentos e transformações, levando a um reposicionamento no mundo que pode causar a ocorrência do inesperado, do surpreendente que a relação de amizade vincula-se a esses "processos de singularização" como vínculo que possibilita o surgimento de registros outros de subjetividade, incompatíveis com os empreendimentos da produção de subjetividade capitalística os quais padronizam e serializam os sujeitos, individualizando-os.

\section{Solidariedade e resistência que desabrocham nos canteiros de amizade}

A dimensão de solidariedade inter-humana da amizade proporciona a ajuda entre amigos estabelecendo vínculos comprometidos com o outro num movimento de recusa do individualismo e práticas excludentes, próprias do neoliberalismo, em que o partilhamento dá o tom de "união de forças", mencionando Arendt (1993) - que a amizade alcança justamente a comunidade. As relações solidárias entre amigos, além de proporcionar aquela acolhida que instaura crescimento em Pedro, Gabriel, e outros, também podem acarretar vínculos de maior união e engajamento, nos quais a força e apoio entre amigos permitem a formação de uma comunidade politicamente organizada, possibilitando transformações políticas. O cuidado generoso nos laços de amizade que caracteriza uma relação de comprometimento com o outro e a mudança que a amizade possibilita instaurar, inspirada pela solidariedade entre amigos, permitindo romper com a condição de espoliação econômica, podem ser compreendidos nas histórias de Girassol, que teve ajuda dos amigos para montar sua casa, além de ter conseguido, com o apoio de amigos, contornar a situação de desemprego, formando a cooperativa. Girassol estava desempregada, pois a dona da lanchonete em que trabalhava fechou o estabelecimento sem fazer o devido pagamento a ela e demais funcionários. Girassol chamou seus amigos e uniu forças para organizar uma lanchonete no mesmo local que funcionaria como cooperativa. Girassol convidou alguns amigos que também eram da antiga lanchonete, esses, por sua vez, também chamaram outros amigos e montaram a cooperativa.

Além de contar com o apoio de amigos para superar a situação de desemprego, foi com a ajuda de um amigo que Girassol e demais cooperados conseguiram contornar um segundo momento de dificuldade de ordem econômica: foi o amigo Francisco que, num gesto de solidariedade, tirou todo dinheiro que tinha de sua conta corrente com a esposa e deu para a cooperativa comprar seus equipamentos de trabalho, permitindo que os cooperados, juntamente, começassem a dar seus primeiros passos:

Se nãofosse ele a gente talvez não tivesse nem os equipamentos que a gente tem hoje quando a gente iniciou, porque coitado o dinheiro era conta conjunta dele e da esposa dele, mas ele tirou 500 reais dessa conta conjunta nem comunicou a esposa e trouxe pra cá, então quer dizer é uma relação de amizade, né, é uma amizade, né, mas estamos aí, estamos junto. (grifos meus) (Girassol)

O gesto generoso de seu Francisco, que investe todo seu dinheiro guardado em beneficio da cooperativa, ilumina a fascinante dimensão de solidariedade entre amigos mobilizada não por interesse individual, mas sim pelo beneficiamento da coletividade. É buscando contribuir com a cooperativa que seu Francisco doa seu dinheiro, acreditando nos amigos e na cooperativa, investindo num bem comum. Diante dos impedimentos advindos de uma expropriação financeira, a relação solidária entre amigos é o que traz humanidade para o movimento de resistência. A mesma ousadia de Girassol, que não se conforma em se ver deixada para trás diante da atitude aviltante desonrosa de sua ex-patroa, revertendo o apuro do desemprego, juntando forças, unindo amigos para formar a cooperativa, resplandece na resistência teimosa do caboclo, do trabalhador rural, como nos informa Candido (2001).

As formas de trabalho coletivo da sociedade caipira desvelam relações solidárias que contribuem de forma essencial para a sustentação da unidade estrutural e funcional do trabalho agrícola. A cooperação vicinal, a união e apoio dos compadres no trabalho no campo compõem formas de solidariedade que suprem o problema da mão-de-obra nos grupos de vizinhança e contribuem para o enfrentamento das dificuldades e urgências próprias do cuidado com as plantações, como no caso de vizinhos que se juntam para malhar ou colher o feijão antes que a chuva estrague, nos chamados mutirões - destacado por Candido (2001).

As relações de ajuda entre as pessoas das classes populares ressaltam a solidariedade nos laços de amizade, configurando vínculos de compromisso com a dignidade humana do outro, no qual a mobilização das pessoas encontra-se articulada com a busca do bem-estar comum, como no caso dos cooperados que dividiam comida entre si e que doaram o primeiro pagamento da cooperativa para comprar um caixão para um irmão falecido de uma cooperada.

Os vínculos de solidariedade e ajuda que visam ao bemestar da comunidade dependem da capacidade de ajuda, do cuidado pelos outros, do reconhecimento do outro como alguém que tem rosto, num compromisso irresistível com a sorte e dignidade dos outros que implica criatividade e o risco assumido para romper automatismos cotidianos - tal como adverte Bauman (2004, p. 94):

A sobrevivência e o bem-estar da communitas (e também, indiretamente, da societas) dependem da imaginação, inventividade e coragem humanas de quebrar a rotina e tentar caminhos nãoexperimentados. Dependem, em outras palavras, da capacidade humana de viver com riscos e de aceitar a responsabilidade pelas conseqüências. São essas capacidades que constituem os esteios da "economia moral" - cuidado e auxílio mútuos, viver para os outros, urdir o tecido dos compromissos humanos, estreitar e manter os vínculos inter-humanos, traduzir direitos em obrigações, compartir a responsabilidade pela sorte e o bem-estar de todos - indispensável para tapar os buracos escavados e conter os fluxos liberados pelo empreendimento, eternamente inconcluso, da estruturação. 
O auxílio que surge no vínculo entre amigos, como vimos, muitas vezes é impelido pelo intuito de buscar o resgate da cidadania num movimento de resistência da condição de impedimento econômico, por meio de práticas solidárias que buscam contribuir para que o amigo conquiste uma certa autonomia num contexto de dominação econômica sentido como extremamente limitante.

Essa atitude de se compadecer, de partilhar, que o laço de amizade inspira emana do gesto de solidariedade, como reconhecimento da situação do outro, na qual se "respira" a vida a partir do seu lugar, como relação que me põe em contato com o exercício político de comprometimento com a dignidade do outro - condição que afeta todo tecido social diretamente.

Como demonstram os discursos, a amizade possibilita esse espaço respeitoso e de experimentação política em que os objetivos e interesses compartilhados mobilizam maior afinco e engajamento, informando o movimento de adesão e companhia dos outros necessários para que as ações políticas perfaçam-se. Não o interesse/objetivo particular, mas o de ordem coletiva mobiliza o apoio e força entre amigos, possibilitando maior união no movimento fundamentado pelo sentido de "lutar junto". Esses vínculos de parceria pautados num espaço de diálogo, de união e apoio engajado, responsável entre amigos que possibilitam o surgimento do surpreendente esclarecem o poder da reunião não-violenta dos homens advertido por Arendt (2001).

\section{Referências}

Arendt, H. (1993). A Dignidade da Política: ensaios e conferências. ( $3^{a}$ ed., H. Martins, Trad.). Rio de Janeiro: Relume Dumará.

Arendt, H. (2001). A Condição Humana (10ª ed., R. Raposo, Trad.). Rio de Janeiro: Forense Universitária.

Bauman, Z. (2004). Amor Líquido: sobre a fragilidade dos laços humanos. (Medeiros, C. A, Trad.). Rio de Janeiro: Jorge Zahar.

Candido, A. (2001). Os Parceiros do Rio Bonito: estudo sobre o caipira paulista e a transformação dos seus meios de vida. São Paulo: Duas Cidades, Ed. 34.

Derrida, J. (1997). Politics of Friendship. (G. Collins, Trad.). New York: Verso.
Derrida, J. (2003). Questão do estrangeiro: vinda do estrangeiro. Em J. Derrida \& A. Dufourmantelle (Orgs.), Anne Dufourmantelle convida Jaques Derrida a falar da Hospitalidade. (A. Romane, Trad., pp. 5-65, ímpares). São Paulo: Escuta.

Dufourmantelle, A. (2003). Convite. Em J. Derrida \& A. Dufourmantelle (Orgs.), Anne Dufourmantelle convida Jaques Derrida a falar da Hospitalidade. (A. Romane, Trad., pp. 4-134 pares). São Paulo: Escuta.

Figueiredo, C. L. \& Coelho Jr., C. E. N. (2003). Patterns of Intersubjetivity in the Constituition of Subjetivity: Dimensions of Otherness. Culture and Psychology, 9(3), 193-208.

Foucault, M. (1981). Da amizade como modo de vida (W. F. Nascimento, Trad.). Entrevista de Foucault a R. De Ceccaty, J. Danet e J. le Bitoux publicada no Jornal Gai Pied, no.25, abril de 1981 (pp. 38-39). Retirado em 4 de abril de 2004 de http://www. unb.br/fe/tef/filoesco/foucault/amitie.html

Guattari, F. \& Rolnik, S. (1986). Micropolítica. Cartografias do Desejo (2a ed.). Petrópolis: Vozes.

Lévinas, E. (1993). Humanismo do outro Homem (P. S. Pivatto, Trad.). Petrópolis: Vozes.

Lévinas, E. (2005). Entre Nós. Ensaios sobre a alteridade (2ª ed., P. S. Pivatto, Trad.). Petrópolis: Vozes.

Ortega, F. (1999). Amizade e estética da existência em Foucault. Rio de Janeiro: Edições Graal.

Ortega, F. (2000). Para uma política da amizade: Arendt, Derrida, Foucault. Rio de Janeiro: Relume Dumará.

Sader, E. (1988). Quando Novos Personagens Entraram em Cena: experiências, falas e lutas dos trabalhadores da Grande São Paulo, 1970-1980. Rio de Janeiro: Paz e Terra.

Silva Júnior, N. da (1999). O abismo fonte do olhar: pré-perspectiva em Odilon Moraes e abertura da situação analítica. Percurso, 23(2), 16-26.

\section{NORMAS DE PUBLICAÇÃO}

São adaptadas de Publication Manual of the American Psychological Association (APA, 5a. Edição, 2001) e podem ser consultadas ao final de cada número (versão impressa ou online) ou no endereço: http://www.revistaptp.org.br 